\title{
Pseudomonas flavescens sp. nov., Isolated from Walnut Blight Cankers
}

\author{
D. C. HILDEBRAND, ${ }^{1}$ N. J. PALLERONI, ${ }^{2}$ M. HENDSON,${ }^{1 *}$ J. TOTH, ${ }^{3}$ AND J. L. JOHNSON ${ }^{3}$ \\ Department of Plant Pathology, University of California, Berkeley, California $94720^{1}$; Department of Microbiology, \\ New York University Medical School, New York, New York 10016 ${ }^{2}$; and Department of Anaerobic Microbiology, \\ Virginia Polytechnic Institute and State University, Blacksburg, Virginia $24061^{3}$
}

\begin{abstract}
Two pseudomonad strains that produce a yellow cellular pigment, in addition to a diffusible fluorescent pigment on Kings medium B, were isolated from cankers on walnut trees. Biochemical properties, such as a positive oxidase reaction, a negative arginine dihydrolase reaction, and the production of a fluorescent pigment, in addition to the results of an extensive nutritional characterization study and DNA-DNA hybridization experiments, indicated that these strains belong to a new Pseudomonas rRNA group I species. This conclusion was supported by the results of a determination of the sequence of the PCR-amplified $16 S$ rRNA gene and a comparison with the 16S rRNA genes of other bacterial species. The genomic DNAs of the strains had a base composition of $63 \mathrm{~mol} \% \mathrm{G}+\mathrm{C}$. The name Pseudomonas flavescens sp. nov. is proposed. Strain B62 (= NCPPB 3063) is the type strain of the species.
\end{abstract}

During a study of Xanthomonas campestris pv. juglandis causing cankers on walnut trees, it was observed that some of the cankers were covered with a bright yellow bacterial mass oozing from the lesions. It was assumed that this material consisted primarily of $X$. campestris pv. juglandis cells, since similar phenomena are not uncommon with cankers caused by other bacterial plant pathogens. However, isolation of bacteria from the lesion revealed that the largest proportion of the bacteria were fluorescent pseudomonads that produce a yellow cellular pigment. $X$. campestris pv. juglandis was also present, although in smaller numbers. In this paper we describe the results of a taxonomic study of this canker-inhabiting pseudomonad and ascribe this organism to a new species, for which the name Pseudomonas flavescens is proposed.

\section{MATERIALS AND METHODS}

Bacterial strains. Two pseudomonad strains were isolated 6 weeks apart from walnut trees in Orinda, Calif. Strain B62 $2^{\mathrm{T}}(\mathrm{T}$ $=$ type strain) was isolated from canker tissue, and strain B62-D5 was isolated from bacterial ooze on a canker. Other strains used for comparative purposes are listed in Table 1. YDCP medium (17) was used for isolation and maintenance of strains.

Nutritional and biochemical characteristics. Denitrification, poly- $\beta$-hydroxybutyrate accumulation, the oxidase reaction, the presence of arginine dihydrolase, and hydrolysis of gelatin, starch, and Tween 80 were examined by using methods described by Palleroni and Doudoroff (23). Rutin glycosidase activity was tested by using the basal medium of Ayers et al. (2) ( $1 \mathrm{~g}$ of ammonium sulfate per liter, $0.2 \mathrm{~g}$ of potassium chloride per liter, $0.2 \mathrm{~g}$ of magnesium sulfate per liter, $15 \mathrm{~g}$ of agar per liter; $\mathrm{pH}$ 7.2) supplemented with rutin and glucose as described elsewhere (5). $\beta$-Glucosidase activity, pectolytic activity, ice nucleation activity, the ability to cause soft rot of potatoes, the production of levan, and hypersensitivity were examined by the methods described previously (9). Carbon source utilization tests were conducted by adding carbon sources $(0.1 \%$, wt/vol)

\footnotetext{
* Corresponding author. Mailing address: Division of Entomology and Plant \& Soil Microbiology, University of California, Berkeley, CA 94720. Phone: (510) 643-8063. Fax: (510) 642-3845.
}

to the mineral base media of Ayers et al. (2) and Palleroni and Doudoroff (23). Most of the carbon stock solutions were sterilized by autoclaving; the only exceptions were the solutions sensitive to heat, which were sterilized by filtration. Cultures were inoculated by placing a $0.03-\mathrm{ml}$ drop of a turbid bacterial suspension on an agar medium. Growth was examined after 3 , 7,14 , and 21 days of incubation at $28^{\circ} \mathrm{C}$. Strains inoculated onto minimal medium plates without any added carbon source were used for comparison. Weak growth was scored as a negative result.

Flagellum characterization. Flagellation was observed by using the method of Hoeniger (10). Grids were shadowed with platinum. Flagella were examined with a Phillips model 200 transmission electron microscope.

Plant inoculation. Bacterial suspensions of the organisms being studied, alone or in mixtures with $X$. campestris pv. juglandis, were inoculated into immature leaves of walnut (Juglans regina) by using Carborundum (9). Shoot tips were also inoculated by means of needle pricks (9).

Pigment analysis. Yellow cellular pigment was observed on YDCP medium (17) and on King media A and B (15). In addition, on King medium $B$ a diffusible fluorescent pigment which was visible under UV light was produced. The yellow cellular pigment was analyzed spectrophotometrically (11). Cells were grown on nutrient agar plates for 4 days and then were scraped off and placed in small beakers. Methanol was added, the mixture was stirred, anhydrous sodium sulfate was added to remove water, and the liquid phase was centrifuged. An absorption spectrum for the supernatant was obtained by using a Cary model 14 double-beam spectrophotometer. Preparations of pigments extracted from Xanthomonas campestris pv. campestris ATCC $33913^{\mathrm{T}}, X$. campestris pv. incanae ATCC $13462^{\mathrm{T}}, X$. campestris pv. juglandis ICPB $411^{\mathrm{T}}$, and $X$. campestris pv. malvacearum ATCC 9924 were used for comparison.

The diffusible fluorescent pigment was analyzed spectrophotometrically by using a Gilford Response II spectrophotometer (Ciba Corning, Oberlin, Ohio). Bacteria were inoculated into King medium B broth (15) and were grown in a shaking incubator at $250 \mathrm{rpm}$ and $28^{\circ} \mathrm{C}$ for $48 \mathrm{~h}$. One milliliter of each culture was centrifuged in an Eppendorf microcentrifuge at $12,000 \times g$ for $2 \mathrm{~min}$, and the absorption spectra of the supernatants were determined. Strains B62 ${ }^{\mathrm{T}}$ and B62-D5 were compared with other fluorescent pigment-producing pseudo- 
TABLE 1. Bacterial strains studied

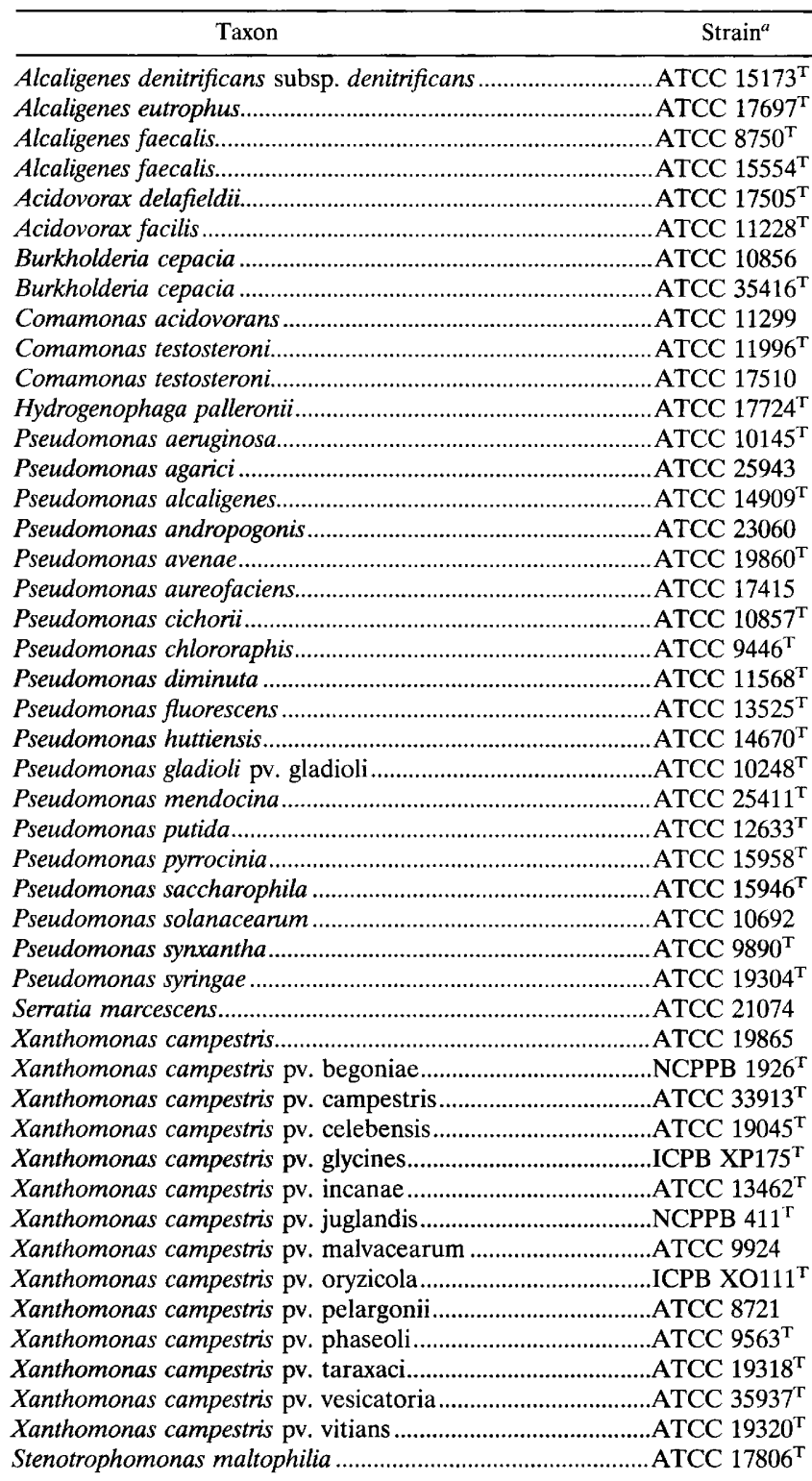

${ }^{a}$ ATCC, American Type Culture Collection, Rockville, Md.; ICPB, International Collection of Phytopathogenic Bacteria, Berkeley, Calif.; NCPPB, National Collection of Plant Pathogenic Bacteria, Hertfordshire, United Kingdom

monads, including Pseudomonas aeruginosa ATCC $10145^{\mathrm{T}}$, Pseudomonas fluorescens ATCC 13525 ${ }^{\mathrm{T}}$, Pseudomonas putida ATCC $12633^{\mathrm{T}}$, Pseudomonas syringae ATCC 19304 ${ }^{\mathrm{T}}$, and Pseudomonas cichorii ATCC $10857^{\mathrm{T}}$. Pseudomonas mendocina ATCC $24511^{\mathbf{T}}$, which produced a yellow cellular pigment but not a fluorescent diffusible pigment, was also used for comparison.

DNA isolation and purification. DNA was isolated and purified by using the method of Marmur (20), as modified by Ballard et al. (3).

DNA base composition. The guanine-plus-cytosine $(\mathrm{G}+\mathrm{C})$ contents of DNAs were determined by thermal denaturation (19) of solutions containing $25 \mu \mathrm{g}$ of DNA per $\mathrm{ml}$ in $0.1 \times \mathrm{SSC}$ ( $1 \times \mathrm{SSC}$ is $0.15 \mathrm{M} \mathrm{NaCl}$ plus $0.015 \mathrm{M}$ sodium citrate, $\mathrm{pH} 7.0$ ), using a Gilford Response II spectrophotometer equipped with a thermoprogrammer. The $\mathrm{G}+\mathrm{C}$ content was estimated by using the melting temperature and the formula of Mandel and Marmur (19). Pseudomonas aureofaciens ATCC 17415 and $P$. putida ATCC $12633^{\mathrm{T}}$ genomic DNA preparations, which had $\mathrm{G}+\mathrm{C}$ contents of 63.6 and $62.5 \mathrm{~mol} \%$, respectively (18), were used as references.

DNA sequence similarity studies. The $\mathrm{S} 1$ nuclease hybridization technique, as described by Johnson and Palleroni (14) and Hildebrand et al. (6), was used to determine the levels of DNA sequence similarity between strain $\mathrm{B} 62^{\mathrm{T}}$ and strains belonging to other Pseudomonas species and pathovars of $X$. campestris (Table 1).

16S rRNA gene DNA sequencing. Genomic DNA was prepared as described above. The 16S rRNA gene sequences were amplified by using the PCR $(21,25)$. The PCR product was sequenced directly $(1,4)$. Each symmetrical PCR mixture contained buffer (50 mM KCl, $10 \mathrm{mM}$ Tris [pH 8.0], $1.5 \mathrm{mM}$ $\mathrm{MgCl}_{2}, 0.1 \%$ Triton X-100), each deoxynucleoside triphosphate at a concentration of $200 \mu \mathrm{M}, 0.5 \mu \mathrm{M}$ oligonucleotide primer 27f, $0.5 \mu \mathrm{M}$ oligonucleotide primer $1525 \mathrm{r}(16), 2.5 \mathrm{U}$ of Taq DNA polymerase (Promega, Madison, Wis.), and $200 \mathrm{ng}$ of DNA per $100 \mu$ l of reaction mixture. The first amplification cycle consisted of denaturation at $96^{\circ} \mathrm{C}$ for $1.5 \mathrm{~min}$, annealing at $48^{\circ} \mathrm{C}$ for $2 \mathrm{~min}$, and elongation at $76^{\circ} \mathrm{C}$ for $4 \mathrm{~min}$. In the 39 other cycles, the heating step was carried out at $95^{\circ} \mathrm{C}$ for 0.5 min. Each symmetrical PCR mixture was electrophoresed in a low-melting-point agarose gel (SeaPlaque agarose; FMC Bioproducts, Rockland, Maine), and the amplification product was excised from the gel. After the preparation was melted at $65^{\circ} \mathrm{C}$ for $15 \mathrm{~min}$, the melted gel was added $(10 \%$, vol/vol $)$ to an asymmetrical reaction mixture which differed from the symmetrical reaction mixture by containing one of the oligonucleotide primers at a concentration of $1 \mu \mathrm{M}$ and the other at a concentration of $0.05 \mu \mathrm{M}$. The asymmetrical amplification reactions were performed for 30 cycles. Both strands of DNA were asymmetrically amplified.

Both DNA strands were sequenced by using the dideoxy sequencing method (26), Sequenase enzyme (United States Biochemical, Cleveland, Ohio), oligonucleotide primers for conserved sequence regions (16), and fluorescent dideoxynucleotides. A Genesis 2000 DNA sequencer (Dupont, Wilmington, Del.) was used.

Approximately $1,450 \mathrm{bp}$ of the $\mathrm{B} 62^{\mathrm{T}} 16 \mathrm{~S}$ rRNA gene sequence were aligned with other $16 \mathrm{~S}$ rRNA gene sequences obtained from GenBank, including the sequences of Comamonas testosteroni (accession number M11224), Burkholderia cepacia (accession number M22518), $P$. aeruginosa (accession number X06684), P. mendocina (accession number M59154), $P$. fluorescens (accession numbers D11188, D11237, and D11286), Pseudomonas diminuta (accession number M59064) Escherichia coli (accession numbers J01859, K02555, M24828, M24911, and M24996), and Stenotrophomonas maltophilia (22a) (accession number M59158). The sequences were aligned and similarity values were calculated by using a personal computer-based multiple-sequence screen editor written by Tommy O. Johnson (Blacksburg, Va.). The unweighted pair group method of cluster analysis (28) was used to generate a dendrogram.

Nucleotide sequence accession number. The DNA sequence obtained in this study has been deposited in the GenBank data base under accession number U01916.

\section{RESULTS}

Biochemical, nutritional, and flagellum characteristics. The two strains of the new species gave identical results in all tests. 


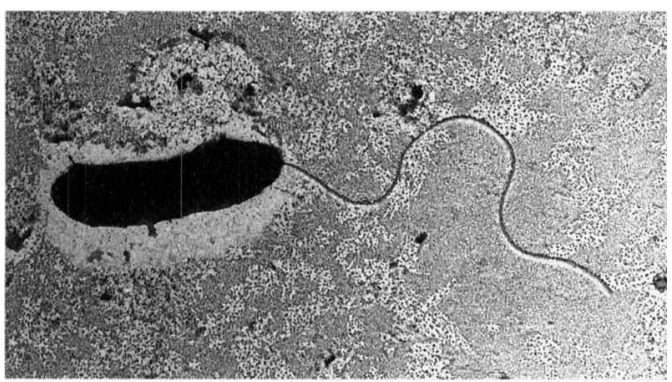

FIG. 1. Electron micrograph of a cell of $P$. flavescens NCPPB $3063^{\mathrm{T}}$, showing the single polar flagellum. Magnification, $\times 12,000$.

Their properties are given below in the species description. A single polar flagellum was observed by transmission electron microscopy (Fig. 1).

Plant inoculation tests. When inoculated by themselves, the strains did not cause any damage to plants, aside from the injury caused by the inoculation process. The bacteria could be reisolated from injured areas 1 month after inoculation. When the strains were coinoculated with $X$. campestris pv. juglandis, the lesions were typical of those caused by $X$. campestris pv. juglandis. Yellow bacteria which resembled strain $\mathrm{B} 62^{\mathrm{T}}$ were also reisolated from the lesions 1 month after inoculation. Yellow ooze was not observed around any of the stem inoculation areas.

Pigment analysis. A spectral analysis of the yellow cellular pigment indicated that it was different from the xanthomonadins characteristic of the genus Xanthomonas. Under the conditions of our analyses, the position of the major peak of pigment extracted with methanol from the xanthomonad reference strains ranged from 442 to $443.5 \mathrm{~nm}$, whereas the major peak of the pigment of the new species was at $446 \mathrm{~nm}$.

A spectral analysis of the supernatants of cultures grown in King medium B broth, a medium which induces production of the fluorescent pigment, revealed a single peak at $405 \mathrm{~nm}$ for strains $\mathrm{B} 62^{\mathrm{T}}$ and B62-D5. Single absorption peaks were observed for $P$. mendocina, $P$. cichorii, $P$. syringae, $P$. putida, $P$. fluorescens, and $P$. aeruginosa at $370,408,410,418,422$, and $448 \mathrm{~nm}$, respectively.

DNA base composition. The genomic DNAs of strains B62 and B62-D5 had a base composition of $63 \mathrm{~mol} \% \mathrm{G}+\mathrm{C}$.

DNA hybridization experiments. DNA sequence similarity was not detectable when DNA from B62 $2^{\mathrm{T}}$ and B62-D5 was hybridized with DNA from $S$. maltophilia or with DNA from $X$. campestris pv. campestris, $X$. campestris pv. pelargonii, $X$. campestris pv. phaseoli, $X$. campestris pv. oryzicola, or $X$. campestris pv. vesicatoria. The levels of similarity with $X$. campestris pv. begoniae, $X$. campestris pv. celebensis, $X$. campestris pv. glycines, $X$. campestris pv. juglandis, $X$. campestris pv. taraxaci, and $X$. campestris pv. vitians ranged from 1 to $5 \%$.

Levels of similarity between B62 ${ }^{\mathbf{T}}$ DNA and DNAs from organisms belonging to Pseudomonas rRNA groups I, II, and III were low (Table 2). The organisms tested included nine Pseudomonas rRNA group 1 species, $B$. cepacia (rRNA group II), and $C$. testosteroni (rRNA group III). The levels of similarity between B62 $2^{\mathrm{T}}$ and members of the genera Alcaligenes, Acidovorax, Hydrogenophaga, and Serratia (Table 1) were less than $1 \%$.

16S rRNA sequencing. The 16S rRNA sequence of strain B62 ${ }^{\mathrm{T}}$ (data not shown) was compared with the sequences of other organisms (Table 3 ). The $16 \mathrm{~S}$ ribosomal DNA sequence similarity values ranged from 95.18 to $97.8 \%$ with the three
TABLE 2. Levels of DNA similarity between $P$. flavescens and various strains of Pseudomonas, Burkholderia, and Comamonas species

\begin{tabular}{|c|c|}
\hline Strain & $\begin{array}{l}\% \text { DNA sequence } \\
\text { similarity }\end{array}$ \\
\hline P. aeruginosa ATCC $10145^{\mathrm{T}}$. & 11 \\
\hline P. alcaligenes ATCC $14909^{\mathrm{T}}$.. & 11 \\
\hline P. mendocina ATCC $25411^{\mathrm{T}}$ & 11 \\
\hline P. agarici ATCC 25943 & 6 \\
\hline P. synxantha ATCC $9890^{\mathrm{T}}$ & 7 \\
\hline P. fluorescens ATCC $13525^{\mathrm{T}}$.. & 7 \\
\hline P. chlororaphis ATCC $9446^{\mathrm{T}}$.. & 11 \\
\hline$P$. putida ATCC $12633^{\mathrm{T}} \ldots \ldots \ldots . .$. & 9 \\
\hline$P$. syringae ATCC $19304^{\mathrm{T}}$. & 7 \\
\hline B. cepacia ATCC $25416^{\mathrm{T}}$. & 11 \\
\hline C. testosteroni ATCC $11996^{\mathrm{T}}$. & 4 \\
\hline C. testosteroni ATCC 17510 & 9 \\
\hline
\end{tabular}

rRNA group I species tested ( $P$. aeruginosa, $P$. mendocina, and $P$. fluorescens). The similarity values were significantly lower with rRNA sequences from members of rRNA homology group II (B. cepacia), group III (C. testosteroni), group IV ( $P$. diminuta), and group V ( $S$. maltophilia). A dendrogram illustrating these results is shown in Fig. 2.

\section{DISCUSSION}

The results of DNA hybridization studies performed with strains $\mathrm{B} 62^{\mathrm{T}}$ and $\mathrm{B} 62-\mathrm{D} 5$ and a comparison of the $\mathrm{B} 62^{\mathrm{T}} 16 \mathrm{~S}$ rRNA gene sequence with the sequences of a number of Xanthomonas and Pseudomonas species indicated that the new organism should be placed in the genus Pseudomonas. In addition, B62 $2^{\mathrm{T}}$ and $\mathrm{B} 62-\mathrm{D} 5$ produce a fluorescent pigment on King's medium B (15), which is characteristic of many rRNA group I pseudomonad species. However, the nutritional characteristics of strains B62 ${ }^{\mathrm{T}}$ and B62-D5 (Table 4) and the low levels of DNA similarity with Pseudomonas rRNA homology group I, II, and III species and with Pseudomonas agarici and Pseudomonas synxantha (Table 2) showed that strains B62 and B62-D5 are quite distinct from other pseudomonads and thus should be designated a new species. These plant-associated strains share many properties with the major groups of phytopathogenic fluorescent pseudomonads (27). They lack the arginine dihydrolase system, but they are oxidase positive. The only other fluorescent pseudomonad known to give similar results in these tests is $P$. cichorii. Overall, the nutritional properties of the new strains are similar to those of Pseudomonas viridiflava and $P$. syringae pv. syringae; the exceptions to this are the capacity of the new strains to utilize itaconate, mesaconate, trehalose, and ethanolamine and their failure to utilize ribose, erythritol, and inositol. Another physiological similarity to the phytopathogenic strains is in the growth rates, which are slower than those of most saprophytic fluorescent pseudomonads (7). The similarities in nutritional properties to other phytopathogenic species suggest the possibility that some of these properties may be related to the capacity to grow in plant tissue, a possibility that deserves further investigation. Despite these findings, the level of DNA similarity between $P$. flavescens and $P$. syringae was only $7 \%$. It has been shown previously by using the S1 nuclease and membrane DNA hybridization methods, respectively, that $P$. syringae exhibits $23 \%$ (14) and $49 \%$ (24) DNA similarity with $P$. cichorii. It is well known that the S1 nuclease method for analyzing levels of DNA similarity results in lower DNA homology values than the membrane methods do (13). Levels of DNA similarity of 
TABLE 3. Levels of sequence similarity for aligned 16S rRNA genes

\begin{tabular}{|c|c|c|c|c|c|c|c|c|c|c|}
\hline \multirow[b]{2}{*}{ Organism } & \multirow[b]{2}{*}{$\begin{array}{l}\text { Accession } \\
\text { no. }\end{array}$} & \multicolumn{9}{|c|}{$\%$ Sequence similarity to: } \\
\hline & & 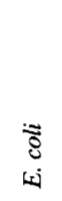 & 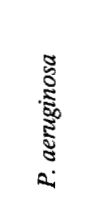 & 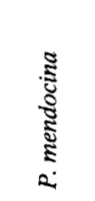 & 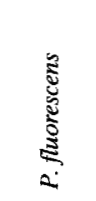 & 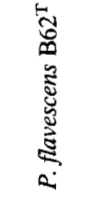 & 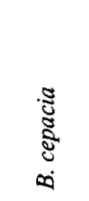 & 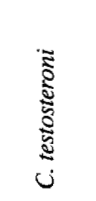 & 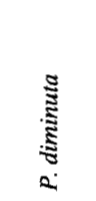 & 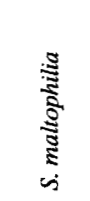 \\
\hline E. coli & - $^{a}$ & 100 & 87.06 & 86.63 & 85.50 & 87.10 & 81.16 & 81.18 & 80.35 & 82.04 \\
\hline P. aeruginosa & X06684 & & 100 & 92.26 & 95.78 & 95.18 & 84.14 & 83.17 & 80.23 & 83.63 \\
\hline P. mendocina & M59154 & & & 100 & 96.89 & 97.80 & 84.83 & 83.69 & 81.26 & 86.35 \\
\hline P. fluorescens & $-^{b}$ & & & & 100 & 96.28 & 84.72 & 83.01 & 82.31 & 82.89 \\
\hline P. flavescens $\mathrm{B} 62^{\mathrm{T}}$ & U01916 & & & & & 100 & 84.87 & 84.45 & 81.22 & 84.99 \\
\hline B. cepacia & M22518 & & & & & & 100 & 89.14 & 80.52 & 84.47 \\
\hline C. testosteroni & M11224 & & & & & & & 100 & 80.52 & 82.31 \\
\hline P. diminuta & M59064 & & & & & & & & 100 & 80.55 \\
\hline S. maltophilia & M59158 & & & & & & & & & 100 \\
\hline
\end{tabular}

${ }^{a}$ Composite of GenBank files J01859, K02555, M24828, M24911, and M24996.

${ }^{b}$ Composite of GenBank files D11188, D11237, and D11286.

37 to $41 \%$ were found for $P$. syringae and $P$. viridiflava (24) by using the membrane method. Since $P$. syringae DNA similarity values were higher with $P$. cichorii and $P$. viridiflava than with strains $\mathrm{B} 62^{\mathrm{T}}$ and $\mathrm{B} 62-\mathrm{D} 5$, it is unlikely that $\mathrm{B} 62^{\mathrm{T}}$ and $\mathrm{B} 62-\mathrm{D} 5$ are closely related to $P$. cichorii and $P$. viridiflava. Data from mathematical models $(8,9)$ indicated that this assumption is correct.

The yellow cellular pigment isolated from $\mathrm{B} 62^{\mathrm{T}}$ and B62-D5 was different from the pigments of the xanthomonads tested. The pigments produced by xanthomonads are unique and consist of brominated aryl-polyenes with an absorption peak at $443 \mathrm{~nm}$ (11). The yellow pigment also differed from the carotenoid pigment (22) produced by nonfluorescent $P$. mendocina (data not shown). Strains $\mathrm{B} 62^{\mathrm{T}}$ and B62-D5 produced a fluorescent pigment with an absorption peak at $405 \mathrm{~nm}$.

A Pseudomonas species similar in some phenotypic properties to the organism described in this paper was proposed under the name Pseudomonas flavida by Itoh et al. (12). The

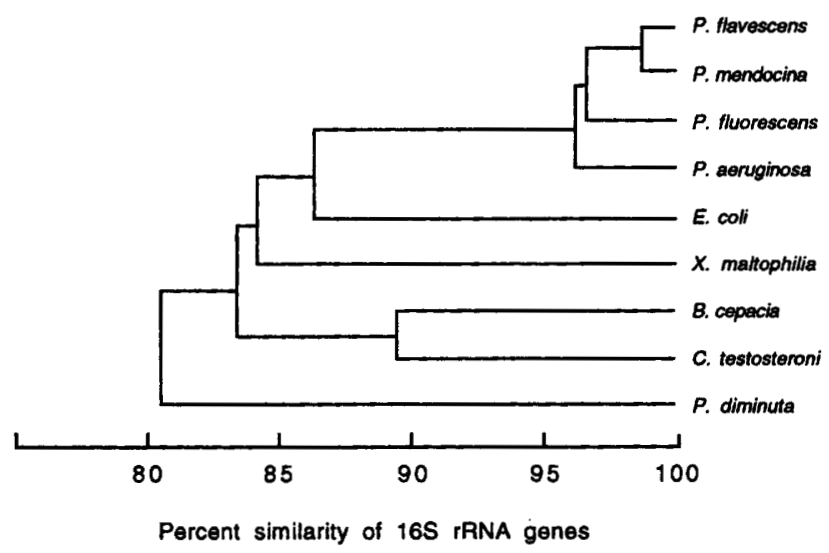

FIG. 2. Dendrogram showing the relationships among $P$. flavescens, E. coli, and strains belonging to Pseudomonas rRNA group I ( $P$. mendocina, $P$. fluorescens, and $P$. aeruginosa), rRNA group II ( $B$. cepacia), rRNA group III ( $C$, testosteroni), rRNA group IV $(P$. diminuta), and rRNA group V ( $S$. maltophilia). The dendrogram is based on levels of similarity of the $16 \mathrm{~S}$ rRNA gene sequences. The unweighted pair method of Sokal and Sneath (28) was used to generate the dendrogram. strain studied by Itoh et al. was isolated from an enrichment culture by using caffeine. The colonies of this organism are yellow, and the cultures also produce a fluorescent pigment. $P$. flavida differs from our strains in being able to utilize caffeine, in having a negative oxidase reaction, in accumulating poly- $\beta$ hydroxybutyrate, and in giving positive arginine dihydrolase and gelatinase reactions. The production of a fluorescent pigment suggests that $P$. flavida is a member of the genus Pseudomonas sensu stricto (rRNA homology group I). The levels of DNA similarity between strain IF-4 of $P$. flavida (kindly sent to us by N. Itoh) and strains B62 ${ }^{\mathrm{T}}$ and B62-D5 were determined by using DNA competition and $\mathrm{S} 1$ nuclease methods. In both cases the level of homology was $0 \%$. This finding supports the conclusion that $P$. flavida is different from the species described in this paper.

The results of a comparison of the rRNA gene sequence of strain $\mathrm{B} 62^{\mathrm{T}}$ with the rRNA gene sequences of Pseudomonas species belonging to rRNA homology groups $\mathrm{I}$ to $\mathrm{V}$ indicated that $B 62^{\mathrm{T}}$ is related to rRNA group $\mathrm{I}$. The most similar sequence was that of $P$. mendocina. This suggests that $\mathrm{B} 62^{\mathrm{T}}$ should be placed in rRNA homology group I. On the basis of all of the properties which we examined, we concluded that strains B62 ${ }^{\mathrm{T}}$ and B62-D5 belong to a new species of the genus Pseudomonas, for which we propose the name Pseudomonas flavescens sp. nov.

Description of Pseudomonas flavescens sp. nov. Pseudomonas flavescens (fla.ves'cens. L.v. flavesco, to become golden yellow; L. part. adj. flavescens, becoming golden yellow). Both strains that have been isolated are aerobic, gram negative, and oxidase positive. The cells are slightly curved rods $(0.6$ to 0.7 by 1.6 to $2.3 \mu \mathrm{m})$ and are motile by means of a single polar flagellum (Fig. 1). They are negative for arginine dihydrolase activity, ice nucleation, and hypersensitivity.

They do not denitrify, nor do they accumulate poly- $\beta$ hydroxybutyrate. Hydrolysis of gelatin, starch, and Tween 80 is negative, and growth does not occur at $37^{\circ} \mathrm{C}$. Colonies are yellow on YDCP medium and King medium B, and a diffusible fluorescent pigment is produced on King medium B. $\beta$-Glucosidase, rutin glycosidase, and pectinolytic enzymes are not produced. These organisms do not cause soft rot of potatoes and do not produce levan. Growth factors are not required. The following compounds are utilized for growth: acetate, cis-aconitate, D-alanine, L-alanine, $\alpha$-aminobutyrate, L-arabi- 
TABLE 4. Characteristics of $P$. flavescens and other Pseudomonas species

\begin{tabular}{|c|c|c|c|c|c|c|c|c|c|c|}
\hline Characteristic & 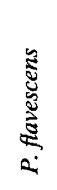 & 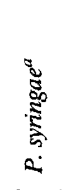 & 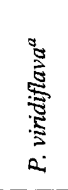 & 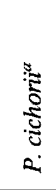 & 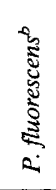 & 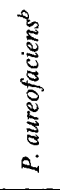 & $\begin{array}{l}\frac{8}{3} \\
\frac{3}{2} \\
\frac{5}{2} \\
0 \\
0\end{array}$ & : & 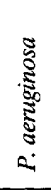 & 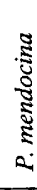 \\
\hline No. of flagella & 1 & $>1$ & $1-2$ & $>1$ & $>1$ & $>1$ & $>1$ & $>1$ & 1 & 1 \\
\hline Growth at $42^{\circ} \mathrm{C}$ & $-c$ & - & - & - & - & - & - & - & - & + \\
\hline Yellow cellular pigment & + & - & - & - & - & - & - & - & - & + \\
\hline Oxidase & + & - & - & + & + & + & + & + & + & + \\
\hline Arginine dihydrolase & - & - & - & - & + & + & + & + & + & + \\
\hline Gelatin liquefaction & - & $\mathrm{d}$ & + & - & + & + & + & - & + & - \\
\hline Hypersensitive response & - & + & + & + & - & - & - & - & - & - \\
\hline Denitrification & - & - & - & - & $\mathrm{d}$ & - & + & - & + & + \\
\hline \multicolumn{11}{|l|}{ Utilization of: } \\
\hline$\beta$-Alanine & - & - & - & - & + & + & + & + & + & + \\
\hline D-Aspartate & - & - & - & + & $\mathrm{d}$ & - & d & $\mathrm{d}$ & - & - \\
\hline Benzoate & - & - & - & - & $\mathrm{d}$ & $\mathrm{d}$ & + & $\mathrm{d}$ & + & d \\
\hline Erythritol & - & $\mathrm{d}$ & + & - & $\mathrm{d}$ & - & - & - & - & - \\
\hline Ethanol & - & - & - & - & $\mathrm{d}$ & - & - & $\mathrm{d}$ & + & + \\
\hline Geraniol & - & - & - & - & - & - & - & - & + & + \\
\hline Hydroxymethylglutarate & + & $\mathrm{d}$ & + & + & $\mathrm{d}$ & - & - & - & - & d \\
\hline Isoleucine & - & - & - & - & + & + & + & + & $\mathrm{d}$ & + \\
\hline L-Lysine & - & - & - & - & $\mathrm{d}$ & $\mathrm{d}$ & $\mathrm{d}$ & $\mathrm{d}$ & + & - \\
\hline D-Malate & + & $\mathrm{d}$ & + & + & $\mathrm{d}$ & - & $\mathrm{d}$ & $\mathrm{d}$ & $\mathrm{d}$ & d \\
\hline Ribose & - & $\mathrm{d}$ & + & + & d & + & + & $\mathrm{d}$ & + & - \\
\hline Isovalerate & - & - & - & - & $\mathrm{d}$ & + & + & + & + & + \\
\hline D-(-)-Tartrate & - & $\mathrm{d}$ & + & - & $\mathrm{d}$ & - & - & $\mathrm{d}$ & - & - \\
\hline $\mathrm{L}-(+)$-Tartrate & - & d & - & + & $\mathrm{d}$ & - & d & $\mathrm{d}$ & - & $\mathrm{d}$ \\
\hline$m$-Tartrate & + & d & + & + & $\mathrm{d}$ & - & - & d & - & - \\
\hline Trehalose & + & - & - & - & $\mathrm{d}$ & $\mathrm{d}$ & + & - & - & - \\
\hline Trigonelline & + & $\mathrm{d}$ & + & + & $\mathrm{d}$ & - & - & $\mathrm{d}$ & - & - \\
\hline L-Tyrosine & - & $\mathrm{d}$ & + & + & + & + & t & + & + & t \\
\hline L-Valine & - & - & - & - & + & + & + & + & $\mathrm{d}$ & + \\
\hline
\end{tabular}

${ }^{a}$ Data from this study and the studies of Hildebrand and Schroth (7), Hildebrand et al. (9), and Paileroni (22).

${ }^{b}$ Data from this study and the studies of Stanier et al. (29) and Palleroni (22).

${ }^{c} \mathrm{~d}, 11$ to $89 \%$ of the strains are positive;,$+ 90 \%$ or more of the strains are positive;,$- 90 \%$ or more of the strains are negative.

nose, L-asparagine, L-aspartate, betaine, 2,3-butanediol, caprate, caproate (slowly), caprylate, choline, citrate, citrulline, creatine, ethanolamine, fumarate, galactose, galacturonate, gluconate, glucose, glutamate, glycerate (slowly), glycerol, glycolate, heptanoate, L-histidine, $p$-hydroxybenzoate, $\beta$-hydroxybutyrate, $\beta$-hydroxymethylglutarate, itaconate, $\alpha$-ketoglutarate, L-lactate, L-leucine, D-malate, L-malate, malonate, mannitol, mannose, mesaconate, mucate, pelargonate, proline, pyruvate, quinate, saccharate, serine (slowly), succinate, sucrose, $m$-tartrate, trehalose, trigonelline, and xylose. The substances not utilized for growth include acetamide, transaconitate, adipate, adonitol, $\beta$-alanine, $\alpha$-aminobutyrate, $\alpha$-aminovalerate, $\delta$-aminovalerate, $\alpha$-amylamine, anthranilate, $\mathrm{D}$-arabinose, L-arabitol, L-arginine, D-aspartate, azelate, benzolate, benzoylformate, benzylamine, butanol, butylamine, butyrate, cellobiose, citraconate, $n$-dodecane, dulcitol, erythritol, ethanol, ethylene glycol, D-fucose, geraniol, glycine, $n$-hexadecane, hippurate, histamine, homoserine, $m$-hydroxybenzoate, $o$-hydroxybenzoate, inositol, insulin, isobutanol, isobutyrate, isoleucine, isovalerate, 2-ketogluconate, kynurenate, kynurenine, lactose, levulinate, L-lysine, maltose, D-mandelate, Lmandelate, melibiose, naphthalene, nicotinate, norleucine, pantothenate, phenol, phenylacetate, phenylalanine, phthalate, pimelate, $n$-propanol, propionate, propylene glycol, ornithine, L-rhamnose, ribose, rutin, salicin, sebacate, sorbitol, sorbose, spermine, starch, suberate, D-(-)-tartrate, L-(+)tartrate, testosterone, L-threonine, D-tryptophan, L-tryptophan, L-tyrosine, and L-valine.
The base composition of the DNA is $63 \mathrm{~mol} \% \mathrm{G}+\mathrm{C}$. The type strain is NCPPB 3063.

\section{ACKNOWLEDGMENT}

We are indebted to Robert L. Gherna of the American Type Culture Collection for his generous help in supplying bacterial strains for comparative studies.

\section{REFERENCES}

1. Aguilar-Cordova, E., and M. W. Lieberman. 1991. Direct sequencing of PCR-amplified genomic DNA. BioTechniques 11:62-65.

2. Ayers, S. H., P. Rupp, and W. T. Johnson. 1919. A study of the alkali-forming bacteria in milk. Bull. U. S. Dep. Agric. 782:1-38.

3. Ballard, R. W., N. J. Palleroni, M. Doudoroff, R. Y. Stanier, and M. Mandel. 1970. Taxonomy of the aerobic pseudomonads: Pseudomonas cepacia, P. marginata, P. alliicola, and P. caryophylli. J. Gen. Microbiol, 60:199-214.

4. Gyllensten, U. B., and H. A. Erlich. 1988. Generation of single stranded DNA by the polymerase chain reaction and its application to direct sequencing of the HLA-DQalpha locus. Proc. Natl. Acad. Sci. USA 85:7652-7656.

5. Hildebrand, D. C., and A. Caesar. 1989. The widespread occurrence of rutin glycosidase in fluorescent phytopathogenic pseudomonads. Lett. Appl. Microbiol. 8:117-119.

6. Hildebrand, D. C., N. J. Palleroni, and M. N. Schroth. 1990. Deoxyribonucleic acid relatedness of 24 xanthomonad strains representing 23 Xanthomonas campestris pathovars and Xanthomonas fragariae. J. Appl. Bacteriol. 68:263-269.

7. Hildebrand, D. C., and M. N. Schroth. 1972. Identification of the fluorescent pseudomonads, p. 281-287. In H. P. Maas Geesteranus 
(ed.), Proceedings of the Third International Conference on Plant-Pathogenic Bacteria. Wageningen, The Netherlands.

8. Hildebrand, D. C., M. N. Schroth, and O. C. Huisman. 1982. The DNA homology matrix and non-random variation concept is the basis for the taxonomic treatment of plant pathogenic and other bacteria. Annu. Rev. Phytopathol. 20:235-256.

9. Hildebrand, D. C., M. N. Schroth, and D. C. Sands. 1988 Pseudomonas, p. 60-80. In N. W. Schaad (ed.), Laboratory guide for the identification of plant pathogenic bacteria, 2nd ed. APS Press, St. Paul, Minn.

10. Hoeniger, J. F. M. 1965 . Development of flagella by Proteus mirabilis. J. Gen. Microbiol. 40:29.

11. Irey, M. S., and R. E. Stall. 1981. Value of xanthomonadins for identification of pigmented Xanthomonas campestris pathovars, $\mathrm{p}$. 85-95. In J. C. Lozano (ed.), Proceedings of the Fifth International Conference on Plant-Pathogenic Bacteria. Centr. Internacional de Agricultura Tropical, Cali, Colombia.

12. Itoh, N., Y. Koide, H. Fukuzawa, S. Irose, and T. Inukai. 1991. Novel plasmid vectors for gene cloning in Pseudomonas. J. Biochem. 110:614-621.

13. Johnson, J. L. 1984. Nucleic acids in bacterial classification, p. 8-11. In N. R. Krieg and J. G. Holt (ed.), Bergey's manual of systematic bacteriology, vol. 1. The Williams \& Wilkins Co., Baltimore.

14. Johnson, J. L., and N. J. Palleroni. 1989. Deoxyribonucleic acid similarities among Pseudomonas species. Int. J. Syst. Bacteriol. 39:230-235.

15. King, E. O., M. K. Ward, and D. E. Raney. 1954. Two simple media for the demonstration of pyocyanin and fluorescin. J. Lab. Clin. Med. 44:474-477.

16. Lane, D. J. 1991. 16S/23S rRNA sequencing, p. 115-175. In E. Stackebrandt and M. Goodfellow (ed.), Nucleic acid techniques in bacterial systematics. John Wiley \& Sons, Ltd., Chichester, England.

17. Leben, C., M. N. Schroth, and D. C. Hildebrand. 1970. Colonization and movement of Pseudomonas syringae on healthy bean seedlings. Phytopathology 60:677-680.

18. Mandel, M. 1966. Deoxyribonucleic acid base composition in the genus Pseudomonas. J. Gen. Microbiol. 43:273-292.

19. Mandel, M., and J. Marmur. 1968. Use of ultraviolet absorbance temperature profile for determining the guanine plus cytosine content of DNA. Methods Enzymol. 12B:195-206.

20. Marmur, J. 1961. A procedure for the isolation of deoxyribonucleic acid from microorganisms. J. Mol. Biol. 3:208-218.

21. Mullis, K. B., and F. Faloona. 1987. Specific synthesis of DNA in vitro via a polymerase catalyzed chain reaction. Methods Enzymol. 155:335-350.

22. Palleroni, N. J. 1984. Genus I. Pseudomonas, p. 141-199. In N. R. Krieg and J. G. Holt (ed.), Bergey's manual of systematic bacteriology, vol. 1. The Williams \& Wilkins Co., Baltimore.

22a.Palleroni, N. J., and J. F. Bradbury. 1993. Stenotrophomonas, a new bacterial genus for Xanthomonas maltophilia (Hugh 1980) Swings et al. 1983. Int. J. Syst. Bacteriol. 43:606-609.

23. Palleroni, N. J., and M. Doudoroff. 1972. Some properties and taxonomic subdivisions of the genus Pseudomonas. Annu. Rev. Phytopathol. 10:73-100.

24. Pecknold, P. C., and R. G. Grogan. 1973. Deoxyribonucleic acid homology groups among phytopathogenic Pseudomonas species. Int. J. Syst. Bacteriol, 23:111-121.

25. Saiki, R. K., D. H. Gelfand, S. Stoffel, S. J. Scharf, R. Giguchi, G. T. Horn, K. B. Mullis, and H. A. Erlich. 1988. Primer-directed enzymatic amplification of DNA with a thermostable DNA polymerase. Science 239:487-491.

26. Sanger, F., S. Nicklen, and A. R. Coulson. 1977. DNA sequencing with chain-terminating inhibitors. Proc. Natl. Acad. Sci. USA 74:5463-5467.

27. Schroth, M. N., D. C. Hildebrand, and M. P. Starr. 1981. Phytopathogenic members of the genus Pseudomonas, p. 701-718. In M. P. Starr, H. Stolp, H. G. Trüper, A. Balows, and H. G. Schlegel (ed.), The prokaryotes. Springer Verlag, New York.

28. Sokal, R. R., and P. H. A. Sneath. 1973. Numerical taxonomy. The principles and practice of numerical classification. Freeman, San Francisco.

29. Stanier, R. Y., N. J. Palleroni, and M. Doudoroff. 1966. The aerobic pseudomonads: a taxonomic study. J. Gen. Microbiol. 43:159-271. 